\title{
ANALISIS SWOT BALANCED SCORECARD (BSC) DALAM KEBIJAKAN PENGEMBANGAN UMKM BATIK SUMINAR DI KABUPATEN KEDIRI
}

\begin{abstract}
Suwarno ${ }^{1}$
Teguh Pramono ${ }^{2}$

Fakultas Ilmu Sosial dan Ilmu Politik Universitas Kadiri, Jawa Timur, Indonesia ${ }^{1,2}$ Email : suwarno@unik-kediri.ac.id ${ }^{1}$,tghpram@unik-kediri.ac.id ${ }^{2}$

ABSTRACT

The policy model strategy in empowering MSMEs in this study uses the Balanced Scorecard as an analysis method. The first stage begins with a SWOT analysis. The SWOT analysis aims to find out how the position of MSMEs is in quadrant positions one, two, three, or four. From the analysis results, it is known that the position of the UMKM batik in Kediri is currently in good condition but faces challenges that must be faced in the future so the strategy that must be carried out is a horizontal integration strategy. The second stage, after the selection of strategic recommendations using the SWOT method, will be measured based on the perspective of the Policy Model that can be implemented in the work program. The four perspectives are Customer Perspective, Financial Perspective, Learning and Growth Perspective, and Internal Business Perspective. The perspective of the policy model covers aspects of venture capital, markets, product quality, marketing, and human resources. Every indicator in the existing policy model must be implemented by applying it in the government policy program.
\end{abstract}

Keywords: SWOT; MSMEs; Balance Scorecard.

\begin{abstract}
ABSTRAK
Strategi model kebijakan dalam memberdayakan UMKM dalam penelitian ini menggunakan Balanced Scorecard (BSC) sebagai metode analisis. Adapun tahap pertama diawali dengan analisis SWOT. Analisis SWOT bertujuan untuk mengetahui bagaimana posisi UMKM berada pada posisi kuadran satu, dua, tiga atau empat. Dari hasil analisis diketahui posisi UMKM batik Kediri saat ini berada pada kondisi baik namun menghadapi tantangan yang harus dihadapi kedepannya sehingga strategi yang harus dilakukan adalah strategi integrasi horizontal. Tahap kedua, setelah terpilihnya rekomendasi strategi dengan menggunakan metode SWOT, akan diukur dengan berlandaskan perspektif Model Kebijakan yang dapat diimplementasikan pada program kerja. Adapun keempat perspektif tersebut adalah Perspektif Pelanggan, Perspektif Finansial, Perspektif Pembelajaran dan pertumbuhan, serta Perspektif Bisnis Internal. Perspektif model kebijakan tersebut mencakup aspek modal usaha, pasar, kualitas produk, pemasaran, dan SDM. Setiap indikator dalam model kebijakan yang ada harus dilaksanakan dengan mengaplikatifkan dalam program kebijakan pemerintah.
\end{abstract}

Kata Kunci: SWOT; UMKM; Balance Scorecard. 


\section{PENDAHULUAN}

Batik telah menjadi salah satu budaya secara turun temurun dan telah ditetapkan oleh UNESCO sebagai budaya asli Indonesia. Batik menjadi aset budaya di Indonesia, karena memiliki nilai historis dan citra eksklusif yang menggambarkan status pemakainya. Oleh sebab itu setiap Kota/Kabupaten di Indonesia memiliki UMKM yang berbasis pada usaha kerajinan batik untuk menggambarkan cirikhas/icon Kota/Kabupaten masing-masing. Selain Kota Surakarta, Kota Cirebon atau Kota Pekalongan, salah satu wilayah penghasil UMKM batik di Indonesia khususnya Provinsi Jawa Timur adalah Kabupaten Kediri.

UMKM yang paling dominan di Kabupaten Kediri saat ini adalah olahan makanaan seperti tahu, namun UMKM Batik menjadi potensial dikarenakan banyaknya agenda besar Kabupaten Kediri yang menjadikan batik sebagai pameran. Selain Batik, Kabupaten Kediri juga memiliki beberapa pusat kerajinan diantaranya, kerajinan tangan, furniture, atau sepatu. Kerajinan batik yang paling popular di Kediri dikenal sebagai batik Suminar. Batik Suminar memiliki 5 (lima) motif khas tersendiri, diantaranya motif flora, motif fauna, motif sosial, motif pariwisata, dan motif seni budaya. Seluruh motif tersebut menggambarkan icon khusus yang ada di Kabupaten Kediri. Batik suminar sendiri telah memiliki joglo batik, sehingga dalam memproduksi sekaligus memasarkan industry kerajinan batik dilaksanakan di joglo tersebut. Corak yang dihasilkan oleh batik Suminar Kediri memiliki corak batik yang khas dan unik, sehingga batik Suminar bisa dijadikan sebagai aset yang besar untuk daya saing antar wilayah. 
Di era saat ini, kain batik yang sedang dibutuhkan oleh masyarakat bukan hanya sebagai alat dalam memenuhi kebutuhan sandang, tetapi keberadaanya banyak dihubungkan dengan pranata sosial masyarakat. Kain batik dengan warna dan motif khusus seringkali menjadi simbol pranata sosial bagi pemakainya. "Banyaknya fungsi dari penggunaan kain batik menjadikan corak dan warna pada batik memiliki peran yang sangat penting" (Polnaya \& Darwanto, 2015). Diharapkan dengan adanya inovasi baru dapat menjadikan keuntungan yang besar bagi pengusaha UMKM batik khususnya di Kabupaten Kediri. Batik Suminar Kediri memiliki nilai sejarah yang cukup tinggi, sebab sejak abad XII terdapat salah satu kerajaan yang terkenal di Kediri yaitu kerajaan Kadiri yang merupakan bagian dari kerajaan Majapahit. Selain memiliki nilai sejarah yang tinggi, Kabupaten Kediri memiliki potensi alam dan wisata yang cukup besar. Potensi yang bersumber dari alam tersebut berupa pertanian, perkebunan, dan perikanan. Sementara itu, potensi yang bersumber dari pariwisata terdiri dari Goa, Pegunungan dan Sungai. Dari kekayaan alam tersebut, munculah ide pembuatan batik yang di gagas oleh Dra. Suminarwati Sundoro pada tahun 1992. selain karena kekayaan alam dan pariwisata, Ibu Suminarwati Sundoro juga tertarik dengan keindahan batik-batik yang ada di Jawa Tengah dan ingin membuat batik Kediri dengan ciri khas sendiri. Batik khas dari Kediri memiliki corak yang menarik untuk digali potensi dari sisi sejarahnya, peninggalan arkeologis, serta perkembangan masyarakat, dan pada akhirnya lahirlah busana kediren, berupa Batik Bolleches dengan nama Garuda Mukha dan teratai mekar dengan warna utama ungu cerah kebiruan atau nila, kuning dan merah soga. 
Daya saing yang tinggi menjadikan batik khas Kediri harus menggali potensi lebih dalam untuk menumbuhkan inovasi baru dalam menunjang kebutuhan pangsa pasar yang ada. Selain itu, dengan adanya inovasi-inovasi baru dapat membantu bisnis skala kecil dalam mendapatkan keuntungan. Inovasi baru yang dibuat dari batik Suminar salah satunya yaitu batik tulis. Seni dalam membatik adalah proses dalam melukis gambar di atas kain untuk dijadikan bahan jadi seperti pakaian. Proses tersebut, harus dilakukan dengan hati-hati dan teliti sebab acapkali seniman batik harus melukiskan serangkaian titik guna mendapatkan sebuah corak batik yang rigit. Hasil akhir dari proses tersebut merupakan sehelai kain batik dengan motif yang menarik, dan bernilai jual tinggi.

Penelitian ini difokuskan untuk menganalisis lebih dalam tentang bagaimana pemetaan potensi UMKM batik dengan karakteristik yang menggabungkan inovasi bisnis, sosial dan institusional pemerintah daerah untuk meningkatkan kinerja pengusaha batik. Penelitian dilakukan di UMKM batik Kabupaten Kediri dikarenakan tempat yang strategis, dan merupakan hasil pemberdayaan UMKM Pemerintah Daerah Kabupaten Kediri (BAPPEDA Kabupaten Kediri, 2019). Adanya peluang partisipasi dalam pengembangan pengusaha batik yang berpengaruh pada peningkatan kesejahteraan masyarakat, mendorong urgensi dilaksanakannya penelitian dengan tujuan pemetaan potensi UMKM batik dan diharapkan mampu meningkatkan kinerja bagi pengusaha batik di Kediri. Lebih dari itu, manfaat dari penelitian ini dapat dirasakan tidak hanya oleh kalangan perguruan tinggi tetapi juga oleh kalangan praktisi yang meliputi pemerintah, masyarakat dan pelaku pasar. 


\section{METODE PENELITIAN}

Penelitian ini di desain dengan dua tahap, yaitu pemetaan isu yang digali dari pelaku dan stakeholder untuk mendapatkan peta masalah yang dihadapi pelaku bisnis kecil dalam mengembangkan inovasi batik tulis. Pada tahap ini pula akan dilakukan penyusunan model kuadran dan diuji melalui pendekatan kualitatif. Tahap ini dilakukan untuk menjawab rumusan masalah, dengan mempertimbangkan tahap pengabdian yang dilakukan. Tahap selanjutnya adalah pemetaan strategi dengan menggunakan pendekatan kuantitatif. Pada tahap ini isu strategis yang didapan akan dikonfirmasi ulang pada stakeholder dengan metode survei. Desain penelitian tersebut mampu membantu peneliti dalam menjawab rumusan masalah pada tahap pertama dan kedua yang berkarakter sebagai rumusan masalah naturalistik (kualitatif). Peneliti berusaha menggabungkan atau memperluas penemuan-penemuannya yang diperoleh dari satu metode dengan penemuan-penemuannya ke metode yang lain. Strategi ini dapat dilakukan dengan melakukan interview kualitatif terlebih dahulu untuk mendapatkan penjelasanpenjelasan yang memadai, lalu dilakukan survey dengan sejumlah sampel untuk memperoleh hasil umum dari suatu populasi (Creswell, 2010).

Adapun populasi dari penelitian ini adalah 20 (dua puluh) karyawan di Batik Suminar, dan 4 (empat) pejabat struktural di Dinas Koperasi dan Usaha Mikro Kabupaten Kediri. Sedangkan teknik sampling penelitian ini menggunakan purposive sampling. Alasan menggunakan teknik tersebut adalah peneliti merasa sampel yang telah diambil lebih memahami mengenai permasalahan yang akan diteliti. Penggunaan teknik purposive sampling dalam penelitian ini adalah peneliti 
lebih memahami bagaimana pola interaksi antara pemerintah (Dinas Koperasi dan Usaha Mikro Kabupaten Kediri) dan pelaku UMKM dalam kebijakan pengembangan UMKM di Kabupaten Kediri.

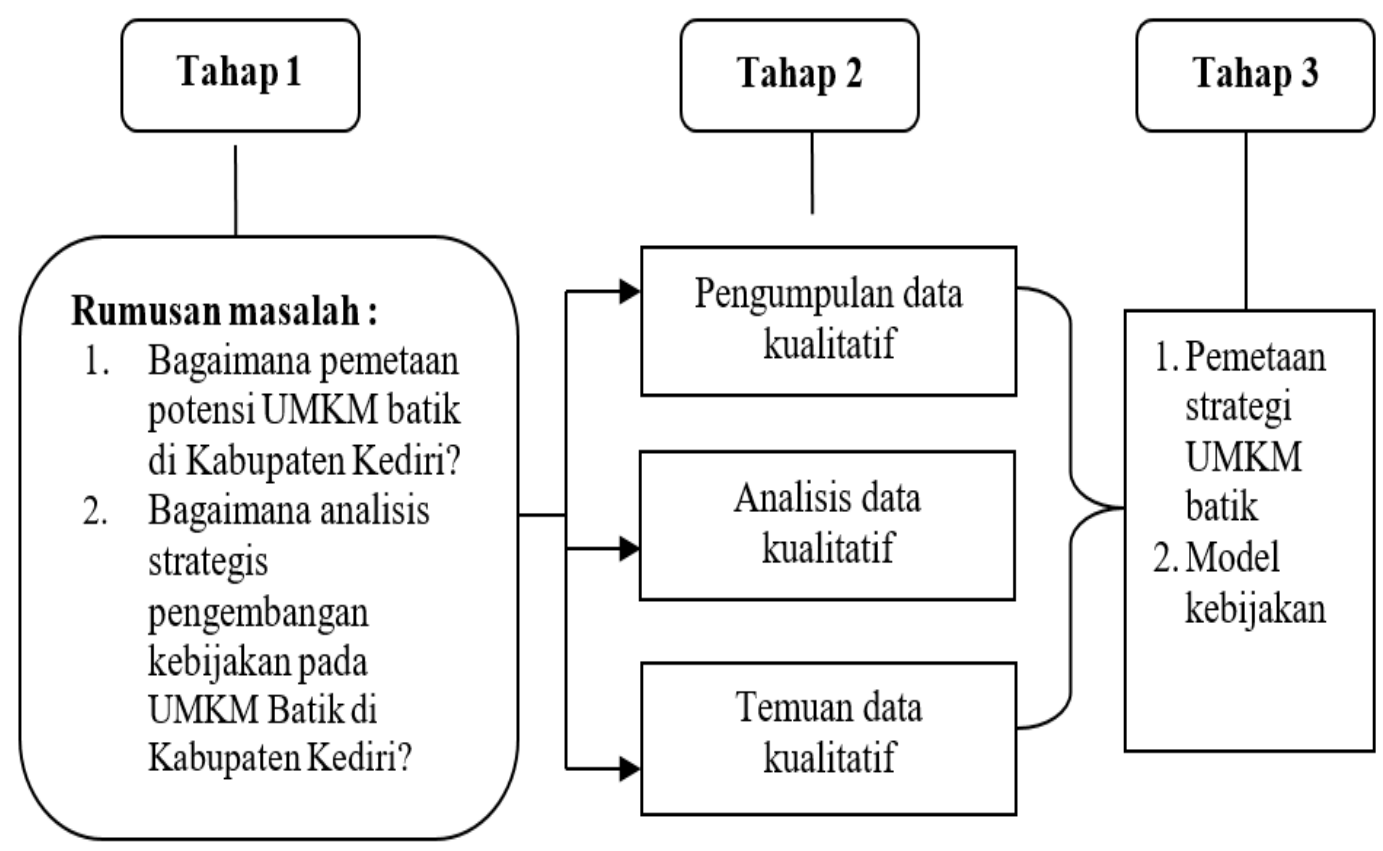

Sumber : (Rangkuti 2017) diolah penulis

Gambar 1. Skema Penelitian SWOT Balanced Scorecard

Dari Gambar 1 terlihat bahwa untuk memetakan permasalahan kinerja pengusaha lokal serta penentuan strategi model kebijakan menggunakan metode SWOT balanced scorecard akan diawali dengan melakukan assessment yang bertujuan untuk mengetahui faktor eksternal dan internal UMKM. Salah satu metode yang paling optimal untuk digunakan dalam melakukan assessment ini adalah Analisis SWOT. Hasil akhir dari assessment dapat dipakai untuk menyusun alternatif strategi yang harus dijalankan oleh UMKM. Dalam konteks tersebut, alternatif strategi dibangun ke dalam 4 (empat) perspektif yaitu perspektif 
pelanggan, proses bisnis internal, finansial, serta pembelajaran dan pertumbuhan. Dalam rangka menunjukan hubungan sebab akibat pada setiap alternatif strategi maka secara konsisten akan disusun peta strategi. Setelah itu, dilakukanlah metode scorecard yaitu tabel yang untuk menentukan target dan capaian setiap strategi.

\section{HASIL DAN PEMBAHASAN}

Untuk mengukur serta mengidentifikasi faktor internal dan eksternal UMKM batik Kediri, peneliti juga menggunakan analisis data menggunakan metode Kuantitatif. Analisis yang dipilih adalah analisis SWOT sedangkan pengukurannya menggunakan metode Balance Scorecard. Pengukuran Balance Scorecard UMKM batik Suminar Kediri akan dimulai dari langkah menentukan kondisi internal dan eksternal UMKM batik Suminar Kediri. Kondisi internal dan Kondisi Eksternal batik yang telah berhasil diidentifikasi ditunjukan pada Tabel 1 dan Tabel 2.

Tabel 1.

Data Internal UMKM batik Suminar

\section{Kekuatan}

\begin{tabular}{ll}
\hline 1. & Dukungan program pelatihan dan pemasaran dari Pemerintah \\
2. & Branding image (citra merek) Batik Kabupaten Kediri \\
3. & Menggunakan peralatan yang sudah modern dan mudah didapat \\
4. & Motif produk yang dihasilkan berasal dari icon Kediri \\
5. & Lokasi penjualan yang strategis dan terdapat Joglo
\end{tabular}

\begin{tabular}{ll}
\hline \multicolumn{1}{c}{ Kelemahan } \\
\hline 1. & Saluran distribusi yang masih belum efisien \\
2. & Kuantitas SDM yang masih kurang \\
3. & Promosi/pemasaran yang masih belum efektif \\
4. & Modal yang ada belum cukup untuk mengembangkan usaha \\
5. & Manajemen organisasi yang belum optimal \\
\hline
\end{tabular}

Sumber: Hasil penelitian

Tabel 2.

Data Eksternal UMKM batik Suminar 


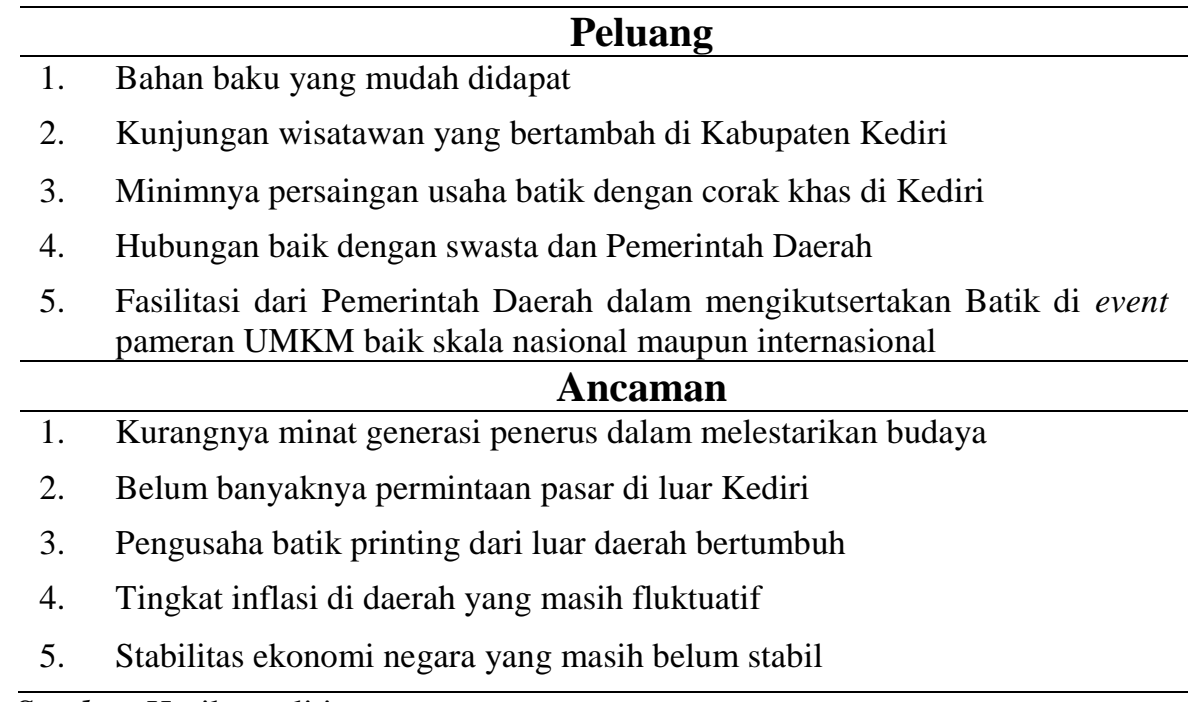

Sumber: Hasil penelitian

Salah satu pendekatan yang dapat dipergunakan sebagai instrumen dalam pemilihan strategi dasar adalah melalui analisis SWOT Rangkuti (2016) menjelaskan bahwa "SWOT analysis" merupakan identifikasi untuk menentukan faktor secara sistematis dan terstruktur untuk merumuskan strategi UMKM batik. Analisis tersebut berdasarkan pada logika yang akan memaksimalkan kekuatan (strengths) dan peluang (opportunities), namun secara bersamaan dapat meminimalkan kelemahan (weakness) dan ancaman (threats).

Analisis dengan menggunakan metode SWOT bertujuan untuk membandingkan faktor eksternal dan faktor internal dari sebuah UMKM. "Faktor eksternal didalamnya terdapat peluang dan ancaman UMKM, sedangkan untuk faktor internal terdiri dari kekuatan dan kelemahan" (Harper, 2000). Setelah ditemukan hasil dari analisis dengan menggunakan metode SWOT, maka tahap selanjutnya adalah melakukan pembobotan/ skoring untuk setiap nilai yang terdapat pada kuadran S (kekuatan), W (kelemahan), O (peluang) dan $\mathrm{T}$ (ancaman). Penilaian akan dilakukan oleh 6 (enam) orang yang dianggap berkompeten pada 
UMKM batik Suminar. Adapun penilaiannya diklasifikasikan dengan angka 1 (satu) hingga 10 (sepuluh) dimana nilai 1 (satu) menunjukan kondisi paling lemah dan nilai 10 (sepuluh) untuk kondisi paling kuat. Demikian pula dengan pembobotan, yang merupakan rata-rata dari penilaian kuisoner seperti yang terlihat pada Tabel 3 sampai Tabel 6 .

Tabel 3.

Skor dan Bobot Strength

\begin{tabular}{clc}
\hline No. & \multicolumn{1}{c}{ Kekuatan } & Skor \\
\hline 1 & $\begin{array}{l}\text { Adanya dukungan program pelatihan dan pemasaran dari Pemerintah } \\
\text { Daerah }\end{array}$ & 8,6 \\
2 & $\begin{array}{l}\text { Sebagai branding image (citra merek) UMKM Batik yang ada di } \\
\text { Kabupaten Kediri }\end{array}$ & 7 \\
3 & Menggunakan peralatan yang sudah modern dan mudah didapat & 8,1 \\
4 & Motif produk yang dihasilkan berasal dari icon yang ada di Kediri & 8,5 \\
5 & Lokasi penjualan yang strategis dan terdapat Joglo untuk membuat batik & 6,2 \\
\hline Total & & $\mathbf{3 8 , 4}$ \\
\hline Sumber: &
\end{tabular}

Tabel 4.

Skor dan Bobot Weakness

\begin{tabular}{|c|c|c|}
\hline No. & Kelemahan & Skor \\
\hline 1 & Saluran distribusi yang masih belum efisien & 6,2 \\
\hline 2 & $\begin{array}{l}\text { Kuantitas SDM yang masih kurang sebab minimnya minat anak muda } \\
\text { untuk membatik }\end{array}$ & 8,6 \\
\hline 3 & Modal yang ada belum cukup untuk mengembangkan usaha & 8 \\
\hline 4 & Promosi/pemasaran yang masih belum efektif & 7,7 \\
\hline 5 & $\begin{array}{l}\text { Manajemen organisasi yang belum optimal (sering terjadi miskomunikasi } \\
\text { antara karyawan dan owner) }\end{array}$ & 7,1 \\
\hline Total & & 37,6 \\
\hline
\end{tabular}

Tabel 5.

Skor dan Bobot Opportunity 


\begin{tabular}{clc}
\hline No. & \multicolumn{1}{c}{ Peluang } & Skor \\
\hline 1 & Bahan baku yang mudah didapat & 9,2 \\
2 & Kunjungan wisatawan yang bertambah di Kabupaten Kediri & 6,5 \\
3 & Minimnya persaingan usaha batik dengan corak khas di Kediri & 8,6 \\
4 & Hubungan baik dengan swasta dan Pemerintah Daerah dalam produksi & 7,6 \\
& dan pemasaran & 5,4 \\
5 & Fasilitasi dari Pemda dalam mengikutsertakan Batik Suminar di event & \\
& Pameran UMKM baik skala nasional maupun internasional & $\mathbf{3 7 , 3}$ \\
\hline Total & & \\
\hline
\end{tabular}

Sumber: Hasil penelitian

Tabel 6.

Skor dan Bobot Threat

\begin{tabular}{clc}
\hline No. & \multicolumn{1}{c}{ Ancaman } & Skor \\
\hline 1 & Kurangnya minat generasi penerus dalam melestarikan budaya membatik & 8,4 \\
2 & Belum banyaknya permintaan pasar di luar Kediri & 8 \\
3 & Pengusaha batik printing dari luar daerah bertumbuh semakin banyak & 7,5 \\
4 & Tingkat inflasi di daerah yang masih fluktuatif & 7,7 \\
5 & Stabilitas ekonomi negara yang masih belum stabil & 8,2 \\
\hline Total & & $\mathbf{3 9 , 8}$
\end{tabular}

Sumber: Hasil penelitian

\section{Sumbu X}

$\geq$ Strength $(\mathrm{S})$ - Weakness $(\mathrm{W})$

$=38,4-37,6$

$=0,8$

\section{Sumbu Y}

$\geq$ Opportunity $(\mathrm{O})$ - Threat $(\mathrm{T})$

$=37,3-39,8$

$=-2,5$

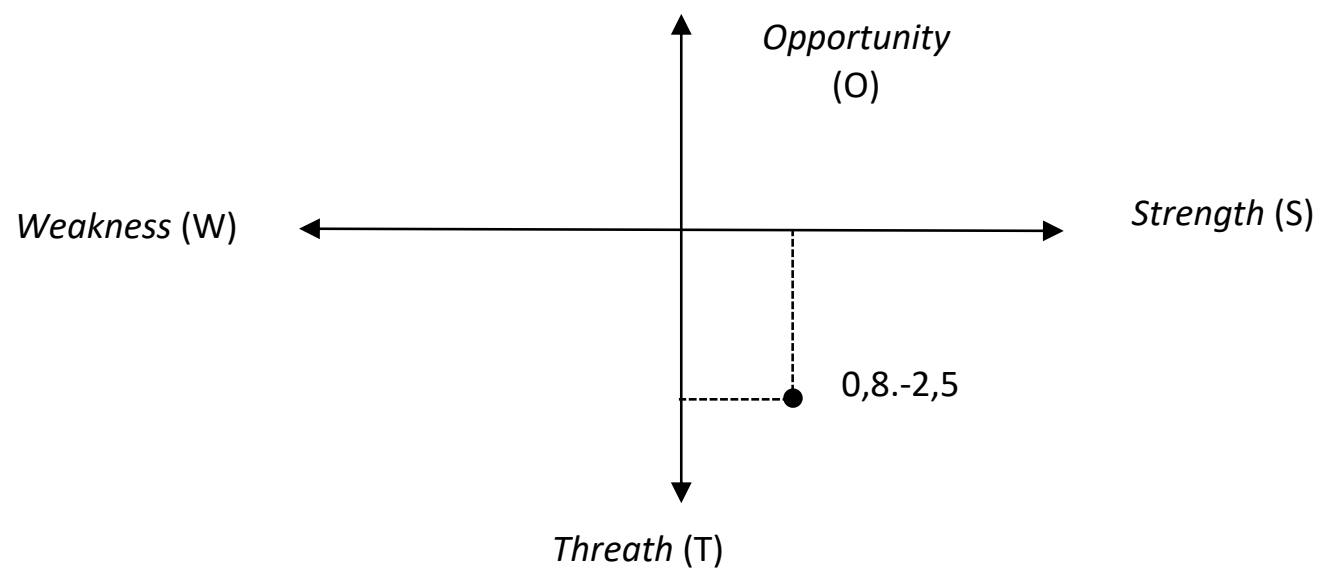

Gambar 2.

Posisi Kuadran SWOT UMKM Batik Kediri 
Bedasarkan Gambar 2, posisi UMKM batik Suminar berada pada kuadran tiga (3). Kuadran 3 berada pada strategi ST (Rangkuti, 2016) artinya menggunakan kekuatan UMKM untuk terhindar/ meminimalisir dampak yang timbul dari eksternal. Hal ini bukan berarti sebuah organisasi akan menghadapi ancaman langsung dari dalam lingkungan eksternal meskipun organisasi ini memiliki kekuatan yang dominan. Sementara itu, berdasarkan matriks kuadran SWOT, menghasilkan nilai/ total skor $(0,8 ;-2,5)$ yang berarti bahwa UMKM batik Suminar Kediri berada diatas rata-rata dari keseluruhan posisi strategisnya dalam usaha untuk meminimalisir hambatan yang biasa saja muncul dan mengoptimalkan peluang yang ada untuk dimanfaatkan. Namun demikian masih terdapat ruang cukup luas untuk peningkatan.

\section{Tabel 5.}

\section{Alternatif Strategi SWOT}

\begin{tabular}{|c|c|c|}
\hline & No & Strategi SWOT \\
\hline \multirow{4}{*}{ 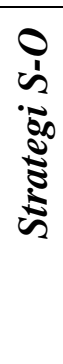 } & 1 & Memberikan akses bahan baku yang lebih luas oleh Pemda \\
\hline & 2 & $\begin{array}{l}\text { Menjadikan UMKM batik Suminar sebagai salah satu destinasi wisata kerajinan di } \\
\text { Kabupaten Kediri }\end{array}$ \\
\hline & 3 & $\begin{array}{l}\text { Mengikutsertakan Batik Suminar di event Pameran UMKM baik skala nasional } \\
\text { maupun internasional }\end{array}$ \\
\hline & 4 & Memperluas jaringan kerjasama baik Pemda maupun Swasta \\
\hline \multirow{5}{*}{ 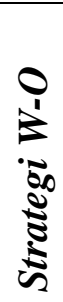 } & 1 & Efisiensi saluran distribusi produk \\
\hline & 2 & Menjadikan canting batik sebagai ekstrakurikuler di sekolah \\
\hline & 3 & Memperbanyak corak khas tentang icon Kediri dalam memproduksi batik \\
\hline & 4 & Meningkatkan kegiatan promosi dengan online marketing yang lebih intensif \\
\hline & 5 & Bimtek manajemen organisasi oleh Pemerintah Daerah \\
\hline
\end{tabular}

\section{Bersambung}

\section{Lanjutan}


Tabel 5.

Alternatif Strategi SWOT

\begin{tabular}{|c|c|c|}
\hline & No & Strategi SWOT \\
\hline \multirow{4}{*}{ 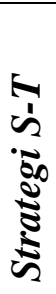 } & 1 & Melakukan riset pengembangan pasar yang lebih luas \\
\hline & 2 & Membuka program franchise terutama untuk kota kota yang belum dijangkau \\
\hline & 3 & $\begin{array}{l}\text { Menegaskan branding image UMKM batik Suminar sebagai batik khas Kabupaten } \\
\text { Kediri }\end{array}$ \\
\hline & 4 & $\begin{array}{l}\text { Melakukan campaign dengan menonjolkan batik Suminar di acara formal } \\
\text { Pemerintah Daerah }\end{array}$ \\
\hline \multirow{4}{*}{$\begin{array}{l}\frac{1}{5} \\
\frac{5}{5} \\
\frac{5}{5} \\
\frac{5}{5}\end{array}$} & 1 & $\begin{array}{l}\text { Meningkatkan kesejahteraan SDM agar semakin produktif dan tertarik untuk } \\
\text { membatik }\end{array}$ \\
\hline & 2 & Melakukan pelatihan SDM secara terstruktur \\
\hline & 3 & Memanfaatkan pemberian bantuan modal secara optimal \\
\hline & 4 & Meningkatkan kepuasan pelanggan untuk menjaga retensi pelanggan \\
\hline
\end{tabular}

Sumber: Hasil penelitian

Menurut (Pearce dan Robinson, 224:2014) terdapat 3 (tiga) strategi apabila posisi sebuah organisasi pada kuadran 3 (tiga) atau kuadran (S-T), yaitu: a) Strategi integrasi horizontal (Horizontal integration) merupakan kondisi dimana suatu UMKM dalam menumbuhkan potensinya menerapkan strategi penggabungan/ akuisisi satu UMKM atau lebih secara bersamaan dan berproses pada tingkatan yang sama dari rantai produksi pemasaran. Penggabungan yang dimaksud bertujuan untuk mengeliminasi pesaing dan membuat UMKM yang sudah terorganisir memiliki akses pasar yang baru. Alasan yang menjadikan Integrasi horizontal merupakan strategi menarik adalah dapat dengan cepat meluaskan cakupan georafis atas kegiatan operasinya, meningkatkan pangsa pasar, memperbaiki pengetahuan, memperluas lini produknya, dan meningkatkan efisiensi penggunaan modal. b) Strategi diversivikasi konsentris (Concentric divessification) merupakan strategi 
dengan penggabungan beberapa UMKM yang saling berkaitan dengan UMKM lainnya sehingga dapat berkerjasama dalam hal pengambangan teknologi, perluasan pasar, ataupun produksi. Dengan strategi diversifikasi ini, jenis usaha baru yang terpilih memiliki tingkat persaingan yang ketat dengan jenis usaha yang telah dimiliki oleh UMKM lainnya. c) Strategi ventura bersama (Joint venture) yaitu, strategi yang dilakukan beberapa unit bisnis dan UMKM untuk membentuk jenis usaha baru namun dimiliki oleh bersama sehingga keuntungan yang di dapatkan pun dibagi secara merata.

Berdasarkan hasil perhitungan skor dan bobot melalui metode SWOT, posisi UMKM Batik Suminar berada pada kuadran 3 (tiga) artinya strategi yang cocok digunakan adalah Integrasi Horizontal (Horizontal integration). UMKM batik Suminar dalam kondisi yang kuat, namun dalam jangka panjang kurang bisa berkembang sebab bertumbuhnya pesaing serupa yang beroprasi pada tahapan yang sama dalam sebuah rantai pemasaran. Oleh sebab itu UMKM batik Suminar perlu melakukan akuisisi satu atau lebih UMKM batik yang beroperasi di lingkungan Kabupaten Kediri. Hal tersebut bertujuan untuk mengurangi pesaing yang ada. Integrasi horizontal dengan melakukan akuisisi UMKM sejenis juga akan berdampak pada luasnya cakupan geografis atas kegiatan produksi dan pemasaran batik seminar. Namun tentunya peran Pemerintah Daerah sangat penting untuk mengintegrasikan pelaku UMKM batik sejenis dalam konteks kebijakan publik

Sasaran Strategi. Setelah diidentifikasi jenis strategi pengembangan melalui metode SWOT, tahap selanjutnya yaitu melakukan identifikasi sasaran. Aktivitas ini bertujuan untuk mengetahui dan memperdalam strategi yang digunakan dalam 
memberdayakan UMKM Batik Suminar, peneliti menggunakan 4 (empat) pendekatan/ perspektif yaitu: 1). Prespektif Finansial yakni peningkatan pendapatan dan variabel pendapatan sektor lain. 2). Prespektif Pelanggan yakni peningkatan kepuasan pelanggan, penegasan branding image, memperluas pasar yang belum dijangkau, dan membuka peluang industri kerajinan batik sebagai destinasi wisata daerah. 3). Prespektif Bisnis Internal yakni efisiensi saluran distribusi produk, meningkatkan program marketing yang lebih kreatif, dan pengembangan motif khas kediri yang lebih inovatif. 4). Prespektif Pembelajaran dan Pertumbuhan yakni mengembangkan minat membatik kepada generasi penerus dan pelajar, melakukan pelatihan membatik secara terstruktur, dan bimtek manajemen organisasi oleh pemerintah daerah.

Peta Strategi Menggunakan Perspektif Balance Scorecard (BSC). "Setiap prespektif pada konsep BSC harus saling terkait”. Artinya didalam memetakan sasaran strategi, setiap indikatornya harus terkait satu sama lain bahkan terkait dengan indikator strategi lainnya (Giannopoulos et al., 2013). Dia juga menambahkan pembuatan peta strategi dapat mempermudah pemecahan masalah yang dialami oleh organisasi sekelas UMKM. Sebab hal tersebut dapat memberikan gambaran mengenai hubungan antara satu prespektif indikator strategi dengan prespektif indikator strategi lainnya. Keuntungan lainnya yang didapatkan dengan membuat peta strategi yaitu, setiap perspektif memiliki hubungan sebab akibat yang mengkomunikasikan arti strategi kepada seluruh bagian UMKM batik Suminar Kediri seperti yang terlihat pada Gambar 3 


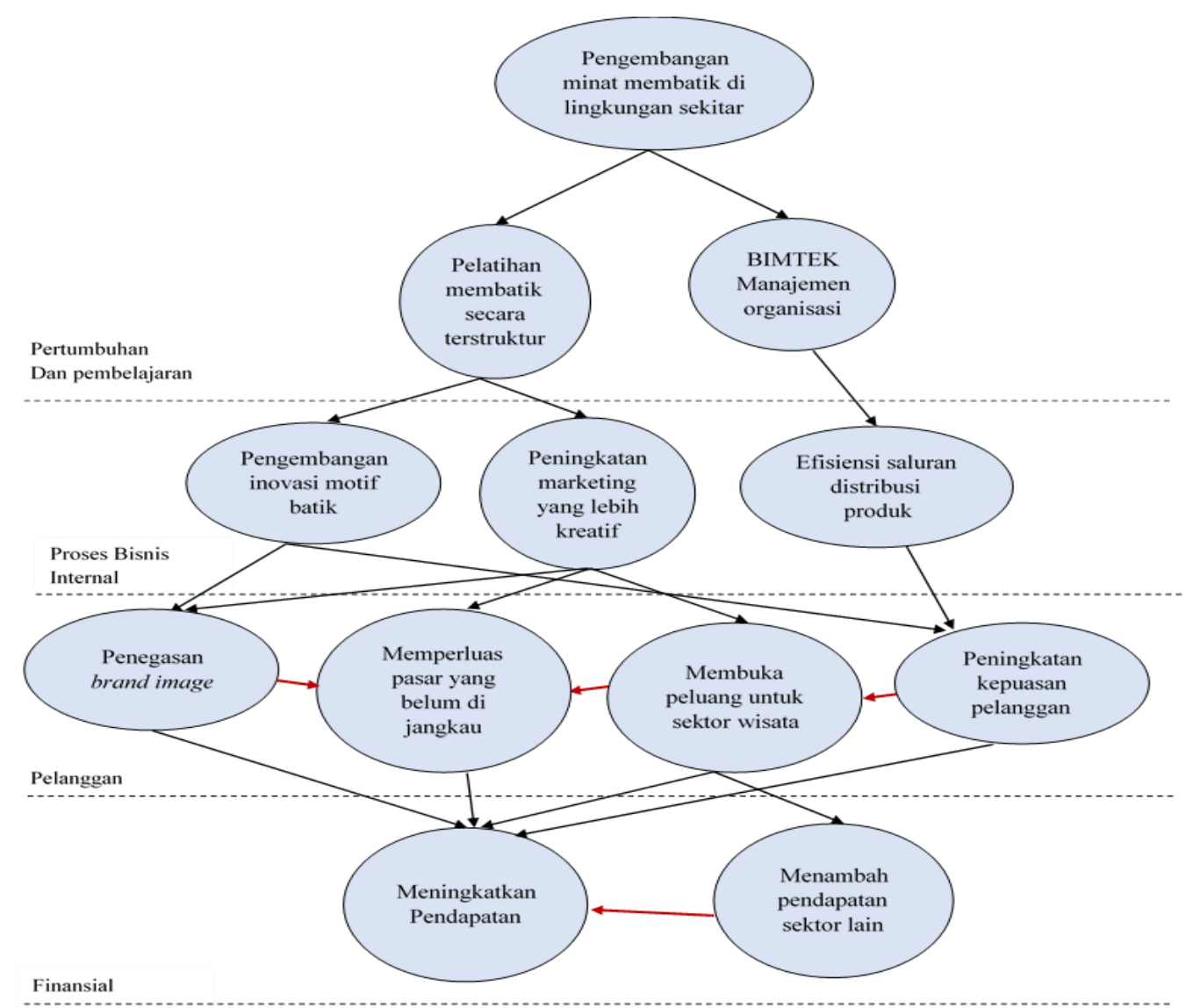

Sumber: Hasil penelitian

Gambar 3.

Peta Strategi UMKM batik Kediri

Tabel 6.

Scorecard Prespektif Finansial

\begin{tabular}{ll}
\hline \multicolumn{1}{c}{ Strategi } & \multicolumn{1}{c}{ Ukuran } \\
\hline Penambahan pendapatan sektor lain & $\begin{array}{l}\text { Terbukanya akses modal dari sektor lain seperti } \\
\text { sektor pariwisata }\end{array}$ \\
\hline Peningkatan pendapatan & Pertumbuhan Pendapatan \\
\hline Sumber: Hasil penelitian & Tabel 7. \\
& Scorecard Prespektif Pelanggan \\
\hline \multicolumn{1}{c}{ Strategi } & Ukuran \\
\hline Penegasan brand image & Jumlah motif yang diakui \\
\hline Memperluas pasar yang belum dijangkau & Market share \\
\hline $\begin{array}{l}\text { Membuka peluang untuk sektor wisata } \\
\text { Meningkatnya kepuasan }\end{array}$ & Jumlah kunjungan wisatawan ke galeri batik \\
\hline Sumber: Hasil penelitian & Indeks kepuasan pelanggan \\
\hline
\end{tabular}

Sumber: Hasil penelitian 
Tabel 8.

Scorecard Prespektif Bisnis Internal

\begin{tabular}{ll}
\hline \multicolumn{1}{c}{ Strategi } & \multicolumn{1}{c}{ Ukuran } \\
\hline Pengembangan inovasi motif & Jumlah produk baru per tahun \\
Peningkatan marketing yang lebih kreatif & Jumlah media promosi yang digunakan \\
\hline Efisiensi saluran distribusi produk & Jumlah complain pelanggan yang tertangani \\
\hline Sumber: Hasil penelitian &
\end{tabular}

Tabel 9.

Scorecard Prespektif Pembelajaran dan Pertumbuhan

\begin{tabular}{ll}
\hline \multicolumn{1}{c}{ Strategi } & \multicolumn{1}{c}{ Ukuran } \\
\hline Pelatihan membatik secara terstruktur & Jumlah peminat membatik yang bertambah \\
BIMTEK Manajemen Organisasi & Produktivitas organisasi \\
\hline Sumber: Hasil penelitian &
\end{tabular}

\section{SIMPULAN DAN SARAN}

Setelah dilakukan analisis terhadap unit usaha dengan menggunakan analisis SWOT, dapat diketahui bahwa UMKM batik Kediri pada saat ini berada dalam kondisi baik namun memiliki ancaman yang harus diperhatikan. Hasil penelitian menunjukkan bahwa strategi baru yang harus dilakukan UMKM batik Kediri adalah strategi dalam memaksimalkan kekuatan untuk mengurangi atau bahkan menghilangkan hambatan. Rekomendasi strategi yang diberikan adalah Integrasi Horizontal (Horizontal integration) artinya UMKM batik Suminar dalam kondisi yang kuat, namun dalam jangka panjang kurang bisa berkembang sebab bertumbuhnya pesaing serupa yang beroprasi pada tahapan yang sama dalam sebuah rantai pemasaran.

Alasan yang menjadikan Integrasi horizontal sebagai strategi pengembangan untuk UMKM Batik Suminar Kediri adalah strategi ini dapat meluaskan cakupan georafis atas kegiatan operasionalnya, membuka pangsa pasar baru, membuka waswasan dan pengetahuan baru, memperluas lini produknya, dan 
lebih mengefisiensikan penggunaan modal. Hasil penelitian memberikan rekomendasi kebijakan kepada pemerintah daerah dengan menyusun program terfokus pada pengembangan UMKM batik Suminar diantaranya: (a) membuka akses modal dari stakeholder lain yang sudah ada saat ini, (b) melaksanakan program penjualan referensi, melakukan pull marketing dan program target marketing, (c) melakukan peneteapan waktu baku penyelesaian produk, (d) melakukan program kompetensi desain, melakukan survei pasar, (e) melakukan program sosialisasi SOP perusahaan kepada karyawan, serta membangun sistem kontrak yang lebih profesional secara full time kepada karyawan, dan memperbaiki cara komunikasi owner terhadap karywannya (f) melakukan penilaian kemampuan SDM yang ada, (g) melaksanakkan program bonus untuk capaian target, dan (h) membangun profil kompetensi. Penelitian ini sudah dilakukan dan dilaksanakan sesuai dengan prosedur dan proses ilmiah, namun dalam penerapannya masih memiliki keterbatasan yaitu: 1). perspektif yang digunakan dalam menentukan bentuk strategi pengembangan UMKM Batik Suminar Kabupaten Kediri hanya terdiri dari 4 (empat) pendekatan yaitu finansial, pelanggan, pembelajaran, dan bisnis internal. 2). adanya keterbatasan penelitian ketika menggunakan metode kuisoner yaitu sedikit jawaban yang diberikan oleh sampel belum menunjukan keadaan sesungguhnya di lapangan.

\section{REFERENSI}

BAPPEDA Kabupaten Kediri. 2019. Kabupaten Kediri Dalam Angka Tahun 2020. https://kedirikab.bps.go.id/publication.html (diakses tanggal 1 Mei 2020)

Creswell, J. W. 2010. Research design: pendekatan kualitatif, kuantitatif, dan mixed. Yogjakarta: PT Pustaka Pelajar. 
Giannopoulos, G., Holt, A., Khansalar, E., \& Cleanthous, S. (2013). The Use of the Balanced Scorecard in Small Companies. International Journal of Business and Management, Vol. 8(14), 1-22.

Harper W, 2000, Manajemen Pemasaran - Suatu Pendekatan Strategis Dengan Orientasi Global edisi 2 jilid 2, Jakarta : Erlangga

Polnaya, G. A., \& Darwanto. (2015). Pengembangan Ekonomi Lokal Untuk Meningkatkan Daya Saing Pada Ukm Ekonomi Kreatif Batik Bakaran Di Pati, Jawa Tengah. Jurnal Bisnis Dan Ekonomi, Vol. 22(1), 1-10.

Pearce, John A. dan Robinson, Richard B. 2014. Strategic Managementformulation, implementation, and control. Salemba Empat. Jakarta

Rangkuti, F. 2016. Teknik membedah kasus bisnis: Analisis SWOT. Jakarta: PT Gramedia Pustaka Utama.

Rangkuti, F. 2017. SWOT Balanced scorecard. Jakarta: PT Gramedia Pustaka Utama. 